\title{
The Attitudes of the Students Enrolled in Jordanian Universities Towards Distance Education During the Coronavirus Pandemic
}

\author{
Nesreen Nabil Rawhe Atieh
}

\begin{abstract}
The study aimed measure the attitudes of the students enrolled in Jordanian universities towards distance education during the Coronavirus pandemic based on three constructs (educational process, evaluation and tests, collaboration and social influence). The sample consists from 150students for university of Jordan. The study used questionnaire. The study found that the students' attitudes towardsdistance education during the Coronavirus pandemic is medium and positive includes (Educational Process Items, Evaluation and Test Items, Collaboration and Social Influence Items). The study also found that there are no significant differences in distance education during the Coronavirus pandemic related to (Gender, Living Place, Education) . the study recommend to provide all the technical and technical requirements for the distance learning process, and to help students acquire appropriate means for distance learning, especially since some of these technologies are expensive.
\end{abstract}

Keywords: Distance Education, Coronavirus Pandemic

DOI: $10.7176 / \mathrm{JEP} / 11-25-07$

Publication date:September $30^{\text {th }} 2020$

\section{Introduction}

The Coronavirus pandemic is considered a global crisis. This virus spread in a short time. It affected the lives and life style of people in many countries. It affected people in social, political, cultural, economic, educational, and technological areas. Hence, many governments took several preventive measures to prevent this virus from spreading. Such measures aim at reducing the severity of the impact of this pandemic. They include:enforcing curfew, and implementingsocial distance policies. They includethe closure of the land, air and maritime borders. They include: the suspension ofactivities in many sectors, including the economic and educational sectors.

Due to this virus, the educational sector has been facing major challenges. The Coronavirus pandemic has many impacts on the educational system and process. Such impacts include: academic and psychological impacts. They include positive and negative impacts. Most of the impacts of the Coronavirus pandemic on the educational sector are considered negative impacts. For instance, the Coronavirus pandemic forced many educational institutions to close temporarily. Such temporary closure led to the spread of concerns among many students. In the light of such conditions, many universities cancelled or postponed many activities and events in the aim of preventing the spread of this virus among students and administrative and academic staff.

The Jordanian Ministry of Higher Education and Scientific Research decided to provide university and school students with online education through using the e-learning platform. That was decided to ensure that the social distance policy is implemented and keep providing students with education. Through using thee-learning platforms, all the Jordanian public and private educational institutions were closed temporarily. However, they kept delivering education to all students during the Coronavirus pandemic. That was done to cover the targeted curricula. All courses were taught through using the e-learning platforms. Tests were administered through using the e-learning platforms. The e-learning platforms were used in accordance with special mechanisms. Through implementing such mechanisms, teachers kept communicating with students and the relevant burdens were reduced.

Distance education via modern communication methods aim at providing students with equal educational opportunities. That is needed in the light of enforcing curfew, and implementing social distance policies during the coronavirus pandemic. Distance education via modern communication methods serves as the only optionfor delivering education during this pandemic. It enables students to adopt a self-learning approach. It enables educational institutions to keep delivering education to students.However, it is associated with several problems. For instance, it may lead to experiencing social isolation. It reduces the extent of social interaction between the ones involved in the educational process. It deprives individuals from establishing social relationships with others. It doesn't ensure that all students are provided with equal opportunities to benefit from e-learning platform.

Distance education is a complex term. To illustrate more, there are several variables that affect the quality of this education. Such variables include: human, technical and administrative variables. The universities that deliver distance education of high quality are the ones that take all those variables into consideration. Refraining from taking any variable into consideration shall negatively affect the quality of such education (Al-Saleh, 2006).

Coronavirus has been spreading for a long period of time. Till today, all countries failed to find a cure for the Coronavirus. Hence, people start tocope with this virus in order for the national and global economy to recover. In the light of such conditions, university students should cope with this situation. That shall enable them to avoid stress. Through distance education, people of all social categories shall definitely receive education. Through such education, numerous students shall receive education. 
After suffering from the Coronavirus for five months, the Jordanian educational institutions started to deliver distance education through using e-learning platforms. Such education aims at promoting collaboration, and meeting the needs of the society's members. It aims at improving the capabilities of the society's members. In order to improve the quality of distance education, several exploratory studies were conducted about the attitudes of students towards such education. In addition, several exploratory studies were conducted about the challenges associated with such education.

Hence, the present study aimed to explore the attitudes of the students enrolled in Jordanian universities towards distance education during the Coronavirus pandemic.

*The present study doesn't represent the opinions of the researcher of the present study. It is just an exploratory study that represents the opinions of the members of the targeted society.

\section{Statement of the Problem and the Study's Questions:}

Due to the exceptional conditions during the Coronavirus pandemic, people adopted a new life style. Due to this virus, a curfew was enforced to prevent the spread of the virus. Due to this virus, all Jordanian universities turned their face-to-face courses into online courses through using e-learning platforms. That was done to ensure that students shall graduate on time. It was done to ensure that the plans for the academic year shall be implemented. In the light of such conditions, the present study aimed to explore the attitudes of the students enrolled in Jordanian universities towards distance education during the Coronavirus pandemic. To be specific the problem of the present study is represented in the following question: (What are the attitudes of the students enrolled in Jordanian universities towards distance education during the Coronavirus pandemic?). There are several sub-questions that are derived from this question. These sub-questions are listed below:

Q.1. What are the students' attitudes towards distance education during the Coronavirus pandemic?

Q.2. What are the students' attitudes towards (Educational Process Items, Evaluation and Test Items, Collaboration and Social Influence Items) during the Coronavirus pandemic?

Q.3.Is there any statistically significant difference - at the statistical significance level of $(\mathrm{a}><0.05)$ - between the students' attitudes towards distance education during the Coronavirus pandemic which can be attributed to (Gender, Living Place, Education)?

\section{The Study's Objectives:}

The present study aimed to:

1) Identify the students' attitudes towards distance education during the Coronavirus pandemic.

2) Identify the students' attitudes towards (Educational Process Items, Evaluation and Test Items, Collaboration and Social Influence Items) during the Coronavirus pandemic.

3) Identify whether there is any statistically significant difference between the students' attitudes towards the towards distance education during the Coronavirus pandemic which can be attributed to (Gender, Living Place, Education).

\section{The Study's Significance: \\ Theoretical significance:}

The present study is significant because it sheds a light on a very important and recent topic. To illustrate more,the coronavirus pandemic has spread recently. It has social, educational and political impacts on all societies, including the Jordanian society. The present study is significant because it sheds a light on e-learning which is very significant. For instance, e-learning plays a significant role in solving educational problems.

The present study is significant becauseit is one of the first few studies that shed a light on this subject. It is significant because it is an attempt to shed a light on the coronavirus pandemic in a scientific manner. It is significant because it can be reviewed by other researchers who want to conduct similar studies that address other aspects.

\section{Practical Significance:}

The present study is significant because it provides officials at the Jordanian Ministry of Higher Education and Scientific Research with information about the students' attitudes towards e-learning. Such information shall enable those officials to address the shortcomings in distance education. It shall enable those officials to improve the strengths of such education. The present study offers data about the students' attitudes towards the educational process during the Coronavirus crisis. It offers recommendations that are based on the reached results.

\section{Definition of the Study's Terms:}

Theoretical definitions:

The researcher defined the study's terms below:

- E-learning: It refers to the provision of education and training through using electronic means, such as: CDs, and internet. He adds that e-learning may be synchronous or asynchronous. Through e-learning, the students 
may adopt a self-learning approach or receive support from the instructor (Al-Harbash, 2003).

- Distance education: It refers to the type of education that falls under open e-learning programs. It is delivered by private and public universities through usinginformation technologies (Sana', 2005). It refers to a new pattern of education in which the learner and the instructor are spatially separated from each other. It involves using a variety of teaching methods and educational means (Haji, 2003).

- Attitude: It refers to one's extent of acceptance fora specific opinion, subject, person or idea (Amasheh, 2014).

- Coronavirus: It refers to a set of viruses that may infect humans and animals.It causes respiratory diseases that range from cold to severe diseases, such as: the Middle East respiratory syndrome-related coronavirus (EMC/2012), the severe acute respiratory syndrome (SARS), and COVID-19 (The World Health Organization (WHO)).

- COVID 19: It refers to a contagiousdisease that is caused by a new strain of coronavirus. It emerged recently. It began spreading in Wuhan, Chine (The World Health Organization (WHO)).

- Pandemic: It refers to any contagiousdisease that spreads in many countries in the world during the same time (The Global Arab Institution, 1996).

\section{Operational definitions:}

Distance education: It refers to the use of e-learning platforms in order to deliver education. It requires using internet and a computer. Through such education, the student may adopt a self-learning approach or receive support from the instructor.

Attitude: It refers to the extent of acceptance of the students enrolled in Jordanian universities for distance education. It is explored through the scale of the present study.

\section{Previous Studies:}

The researcher reviewed several studies that address the same topic. These studies are presented below: 1) -A study titled: (Coronavirus and distance education: The Ministry of Education in Jordan).

The latter study was conducted by the Strategic Studies Centre in the University of Jordan. It falls under a set of surveys titled (The Jordanian indicator- The public opinion of Jordanian on the street). It was conducted during the period (4-7/4/2020). The latter set ofsurveys collects data from a sample that consists from several members of the Jordanian society. This sample was selected from all the Jordanian cities. It includes individuals of various age and academic qualifications. After collecting data, data weighting was conducted. The margin of error doesn't exceed $\% 3 \pm$. The sample of the latter study includes individuals whose ages are within the range of (6-18) years old. The members of the sample are enrolled in public schools. The latter study aimed to shed a light on the public opinions about 17 e-learning platforms and TV channels that were employed by the Jordanian Ministry of Education during the curfew for providing students with education.

\section{The following results were reached through the latter study:}

-Most respondents $(80 \%)$ use the e-learning platforms and TV channels that were employed by the Jordanian Ministry of Education. The quality of the distance education delivered through such e-learning platforms and TV channels is less than the quality of the face-to-face school education

-Half of the respondents believe that there isn't any difference between the education delivered through e-learning platforms and the educational delivered through TV channels in terms of quality.

-Half of the users of (Darsak) Platform faced technical problems during the registration and use of this platform. $-55 \%$ of the students use (Darsak) Platform which is created by the Jordanian Ministry of Education. $61 \%$ of the students are either highly or moderately satisfied with this platform.

Most of the users of (Darsak) Platform (72\%) are satisfied with the performance of the teachers who teach through this platform. To be more specific, $26 \%$ of the users of (Darsak) Platform are highly satisfied with the performance of the teachers who teach through this platform. $46 \%$ of the users of (Darsak) Platform are moderately satisfied with the performance of the teachers who teach through this platform.

-Half of the students (51\%) watch the school lessons broadcasted through the TV channels (i.e. Jo desk 1 and Jo desk 2). $66 \%$ of the students whowatch the school lessons broadcasted through the TV channels are either highly or moderately satisfied with these TV channels.

-Most of the students who watch the school lessons broadcasted through the TV channels (74\%) are either highly or moderately satisfied with the performance of the teachers giving such lessons. $27 \%$ of the students who watch the school lessons broadcasted through the TV channels are highly satisfied with the performance of the teachers giving such lessons. $47 \%$ of the students who watch the school lessons broadcasted through the TV channels are moderately satisfied with the performance of the teachers giving such lessons.

-Half of the students (53\%) use Darsak Platform or watch the lessons broadcasted on TV channels in a daily manner. $21 \%$ of the students use Darsak Platform or watch the lessons broadcasted on TV channels once every two days 
$-80 \%$ of the students who use Darsak Platform or watch the lessons broadcasted on TV channels are either highly or moderately satisfied with the instruction given in the Arabic language course. $76 \%$ of the students who use Darsak Platform or watch the lessons broadcasted on TV channels are either highly or moderately satisfied with the instruction given in the science course. $72 \%$ of the students who use Darsak Platform or watch the lessons broadcasted on TV channels are either highly or moderately satisfied with the instruction given in the math course. About half of the parents of the students who use Darsak Platform or watch the lessons broadcasted on TV channels are satisfied with the instruction given in the English language course.

2)- Awad and Hals (2015) aimed to explore the graduate students' attitudes towards online learning in Palestine. They aimed to explore the relationship between such education and other variables. The sample consists from 91 female and male graduate students who were enrolled in the faculty of education at Palestinian universities. The latter researchers adopted a descriptive analytical approach. Several results were reached by the latter researchers. For instance, graduate students in Palestinian universities have positive attitudes towards online learning. In addition, there isn't any statistically significant difference between the respondents' attitudes towards online education which can be attributed to gender, program level, or academic achievement. However, there is a statistically significant difference between the respondents' attitudes towards online education which can be attributed to university. The latter difference is for the favour of the graduate students who were enrolled in the Islamic University.

3)- Kandilingec (2015) aimed to explore the attitudes of students in technical and vocational secondary schools for girls towards e-learning. He aimed to explore the relationships between such attitudes and several variables. The sample consists from 119 female students. It was found that there isn't any statistically significant difference between the respondents' attitudeswhich can be attributed to gender and experience.

4)-Al-Shunak et al. (2003)aimed to explore the impact of the (lab dry) strategy on the academic achievement of the students enrolled in the faculty of science. They aimed to explore the impact of the (lab dry) strategy on the students' attitudes towards the course. . They aimed to explore the impact of the (lab dry) strategy on the acquisition of skills. The sample consist from 142 female and male students. Those students were selected from the chemistry course. They were divided into control and experimental groups. The experimental group consists from 84 female and male students. The control group consists from 58 female and male students. It was found that there is a statistically significant difference -at the statistical significance level of $(\mathrm{a}=0.05)$ - between the students' attitudes which can be attributed to the teaching method. It was found that there is a statistically significant difference -at the statistical significance level of $(\mathrm{a}=0.05)$ - between the students' academic achievement levels which can be attributed to the teaching method. It was found that there is a statistically significant difference -at the statistical significance level of $(\mathrm{a}=0.05)$ - between the students' extent of acquiring skills which can be attributed to the teaching method. The latter differences are for the favour of the (dry lab) strategy.

5)- Al-Harbi (2016) conducted a study titled (the obstacles associated with distance education from the perspective of the students enrolled at King Abed Al-Aziz University). He aimed to explore the obstacles associated with distance education from the perspective of the students enrolled at King Abed Al-Aziz University. He aimed to explore the impact of faculty, gender, and age on students' attitudes towards such obstacles. The sample consist from 200 female and male BA students. A questionnaire was used. It consists from 20 items. A descriptive analytical approach was adopted by the latter researcher. The results mentioned below were reached by the latter researcher:

- There is a statistically significant difference between the students' attitudes towards such obstacles which can be attributed to faculty. The latter difference is for the favour of the students enrolled at the economy and management faculty.

- There is a statistically significant difference between the students' attitudes towards such obstacles which can be attributed togender. The latter difference is for the favour of the male students.

- There is a statistically significant difference between the students' attitudes towards such obstacles which can be attributed to age. The latter difference is for the favour of the students whose ages are within the range of (11-21) years old. Several recommendations were suggested by the latter researcher.

6)- Conna (2007) aimed to explore the obstacles associated with online courses in secondary schools. The sample consists from 270 principals. It was found that the most significantobstacles are: financial obstacles followed by technological obstacles. The obstacles associated with such courses include: the teachers' beliefs about the quality of e-learning. They include the attention provided by teachers to students' motivation

7)- Anderson (2008) aimed to explore the most significant challenges associated with e-learning in Sri Lanka. The sample consists from 1887 individuals. A quantitative approach was adopted to identify such challenges. A qualitative approach was adopted too to interpret the reasons behind considering the challenges significant. It was found that there are many challenges faced by students and instructors in this regard. It was found that students face more challenges than instructors in this reagard.

8)- Al-Zahrani (2020) conducted a study titled (the attitudes of the faculty members in Um Al-Qurra University towards employing e-learning features: The use of Blackboard Platform in the educational process to address the 
implications caused by curfew due to the Coronavirus). She aimed to explore the attitudes of the faculty members in Um Al-Qurra University towards employing the e-learning features that are providedby the Blackboard Platform. The sample consists from 90 faculty members who were selected from Um Al-Qurra University. It was found that there isn't any statistically significant difference between the respondents' attitudes towards e-learning which can be attributed to (gender, major or academic qualification).

\section{Comments on the Aforementioned Studies:}

Some of the aforementioned studies shed a light on the distance education received by graduate students. Some of the aforementioned studies shed a light on the distance education received by school students. Some of the aforementioned studies shed a light on faculty members' attitudes towards distance education. Some of the aforementioned studies shed a light on the e-learning that aim to address the implications caused by curfew due to the Coronavirus.

The present study differs from the aforementioned studies. For instance, it targets public and private universities in Jordan. It targets students from various majors. Such major include: scientific and human sciences. The members of the sample of the present study differ in terms of characteristics. The present study sheds a light on distance education during the coronavirus pandemic. It sheds a light on students' attitudes towards distance education during the coronavirus pandemic.

\section{Methodology}

In line with the aim of this study, the main purpose of this questionnaire is to measure the attitudes of the students enrolled in Jordanian universities towards distance education during the Coronavirus pandemic based on three constructs (educational process, evaluation and tests, collaboration and social influence). The survey will contain mainly two parts. The beginning of the survey includes introduction about the study to ensure that students understand what they filling about. The first part of the survey will be designed to determine some of students' demographic factors which include: gender, age, education, nationality, college, living place and the sector of educational institution. The second part of the survey will be designed to determine the main factors influencing students'attitudestoward e-learning during Coronavirus pandemic in Jordanian universities. It will be involved 20 questions related with three factors include educational process, evaluation and tests, collaborative and social influence.

\subsection{Sampling and Data Collection}

Linda et al., (2008) mentioned that when researchers formulate their research, they have to verify that their work will accurately fit the respondents in which they are interested. The target population for this study includes university students from different Jordanian universities. Questionnaire will be utilized as a technique to survey a random sample with a sample size about 159 students. Nine surveys were eliminated because of sever missing values. The total number of completed surveys was 150 . The data collected were keyed into the statistical package for social sciences (SPSS). The demographics of the sample used are showed in Table 1. The result of demographics analysis showed that most of respondents are Jordanian (88.7), the majority of them are females (61.3), and most of them had a bachelor degree (77.3) and living in cities (90.7).

Table 1: Demographic Data of the Sample

\begin{tabular}{|c|c|c|c|c|c|c|c|c|}
\hline \multicolumn{3}{|c|}{ Living Place } & \multicolumn{3}{c|}{ Education } & \multicolumn{3}{c|}{ Gender } \\
\hline Category & Freq. & $\%$ & Category & Freq. & $\%$ & Category & Freq. & $\%$ \\
\hline City & 136 & 90.7 & Bachelor & 116 & 77.3 & Male & 58 & 38.7 \\
\hline Village & 7.3 & 7.3 & Master or PhD & 22 & 14.7 & Female & 92 & 61.3 \\
\hline Camp & 2 & 3 & Diploma & 12 & 8.0 & Total & 150 & 100.0 \\
\hline Total & 150 & 100.0 & Total & 150 & 100.0 & \multicolumn{3}{c|}{ Nationality } \\
\hline
\end{tabular}

\subsection{Results and Discussion}

In order to understand the level of perceptions related to educational process, evaluation and test, and collaboration and test to measure the attitudes enrolled in Jordanian universities towards distance education during the Coronavirus pandemic. We estimated the means and standard deviations of each item and the total construct.

Results of Q.1. What are the students' attitudes towards distance education during the Coronavirus pandemic?

Table 2 depicts the means and standard deviations of students' attitudes towardsdistance education during the Coronavirus pandemic. 
Table 2: Means and Standard Deviations of Study variables

\begin{tabular}{|l|l|c|c|}
\hline & Variables & Mean & SD \\
\hline 3 & Collaboration and Social Influence Items & 3.56 & 0.715 \\
\hline 1 & Educational Process Items, & 2.90 & 0.944 \\
\hline 2 & Evaluation and Test Items, & 2.87 & 0.948 \\
\hline & Total & 3.01 & 0.654 \\
\hline
\end{tabular}

Based on table (2), the students' attitudes towardsdistance education during the Coronavirus pandemic is medium and positive. That is because the overall mean is (3.01) which is medium. The overall standard deviation is (0.654). the first rank is for variable Collaboration and Social Influence Items with medium and positive attitudes because the mean is (3.56), and the second rank is for variable Educational Process Items which is mediumand positive because the mean is (2.90). The third rank is for variable Evaluation and Test Items which is medium and positive because the mean is (2.87).

These results may be attributed to the fact that students are not compatible with distance education to a large extent, and students have been forced to enroll in distance education due to the Corona virus crisis, and most universities try to provide all requirements related to distance education, so that students and faculty members can complete the education process easily and more efficiently.

These results are consistent with the results of Conna (2007) study that have shownmost significant obstacles of online courses are: financial obstacles followed by technological obstacles. Anderson (2008) also found that there are many challenges faced by students and instructors in e-learning and students face more challenges than instructors.

The Strategic Studies Centre in the University of Jordan study (2020) about Coronavirus and distance education reported that quality of the distance education delivered through such e-learning platforms and TV channels is less than the quality of the face-to-face school education.

Results of Q.2. What are the students' attitudes towards (Educational Process Items, Evaluation and Test Items, Collaboration and Social Influence Items) during the Coronavirus pandemic

Table 3 depicts the means and standard deviations of students' attitudes towardsvariables related to distance education during the Coronavirus pandemic which is consist of (Educational Process Items, Evaluation and Test Items, Collaboration and Social Influence Items).

Table 3: Table 2 depicts the means and standard deviations of students' attitudes towards variables related to distance education during the Coronavirus pandemic.

\begin{tabular}{|l|l|c|c|}
\hline Code & Educational Process Items & Mean & SD \\
\hline EPI 1 & I think that distance education is a good strategy during Covid19 & 2.95 & 1.442 \\
\hline EPI 2 & I think that e-learning platforms shall be beneficial for students & 2.68 & 1.310 \\
\hline EPI 3 & I think that e-learning strategy is an applicable & 2.95 & 1.307 \\
\hline EPI 4 & $\begin{array}{l}\text { I think that the teaching methods used in e-learning are the same ones used } \\
\text { in traditional lectures }\end{array}$ & 2.61 & 1.295 \\
\hline EPI 5 & $\begin{array}{l}\text { I think that the traditional teaching methods are more effective than e- } \\
\text { learning methods }\end{array}$ & 2.41 & 1.317 \\
\hline EPI 6 & $\begin{array}{l}\text { I think that the time schedule is appropriate in order for students to } \\
\text { comprehend information }\end{array}$ & 3.02 & 1.282 \\
\hline EPI 7 & $\begin{array}{l}\text { I think that the students through distance education shall comprehend } \\
\text { in traditional education }\end{array}$ & 2.62 & 1.267 \\
\hline EPI 8 & $\begin{array}{l}\text { I think that distance education shall increase the extent of doing } \\
\text { assignments by students }\end{array}$ & 3.11 & 1.398 \\
\hline EPI 9 & $\begin{array}{l}\text { I think the distance education shall enable female and male students to } \\
\text { improve their academic performance }\end{array}$ & 3.83 & 1.292 \\
\hline Overall Average & $\begin{array}{l}\text { Evaluation and Test Items } \\
\text { I think taking exams online is easier than taking exams through the } \\
\text { traditional way }\end{array}$ & 3.28 & 1.389 \\
\hline ETI 1 & $\begin{array}{l}\text { I think that I am being assessed in an ongoing manner through distance } \\
\text { ETI 2 }\end{array}$ & 3.01 & 1.185 \\
\hline ETI 4 & \begin{tabular}{l} 
I feel that marks are given in a fair manner through distance education \\
\hline
\end{tabular} & 2.89 \\
\hline
\end{tabular}




\begin{tabular}{|c|c|c|c|}
\hline Code & Educational Process Items & Mean & SD \\
\hline \multirow[t]{3}{*}{ ETI 5} & $\begin{array}{l}\text { I think that the distance education improves students' performance } \\
\text { efficiency }\end{array}$ & 2.82 & 1.306 \\
\hline & Overall Average & 2.87 & 0.948 \\
\hline & Collaboration and Social Influence Items & & \\
\hline CSI 1 & $\begin{array}{l}\text { I think that there is much interaction between students and instructions } \\
\text { through distance education }\end{array}$ & 3.05 & 1.276 \\
\hline CSI 2 & I think that the distance education lacks human interaction & 3.67 & 1.349 \\
\hline CSI 3 & $\begin{array}{l}\text { I think that there is difficult to establish social relationships through } \\
\text { distance education }\end{array}$ & 3.79 & 1.270 \\
\hline CSI 4 & I feel socially isolated when I receive distance education & 3.68 & 1.352 \\
\hline CSI 5 & I feel comfortable when studying for an e-course & 2.59 & 1.371 \\
\hline \multirow[t]{2}{*}{ CSI 6} & $\begin{array}{l}\text { I think that the distance education shall facilitate the process of } \\
\text { exchanging expertise between students and their instructors }\end{array}$ & 2.71 & 1.287 \\
\hline & Overall Average & 3.56 & 0.715 \\
\hline
\end{tabular}

Table 2 shows the students' responses on the statements about the distance learning in Jordanian universities. It clarifies that the means are between (3.01) and (3.83). This means that the respondents have agreed to 9 items of the distance learning, 3 items related with EPI, 2 items connected with ETI and 4 items related with CSI, as their means were greater than the theoretical average 3. According to evaluation process items, the responses of students revealed that EPI 6, EPI 8 and EPI 9 are positive responses with mean(3.02), (3.11) and (3.83) respectively.In respect to evaluation and test items, the responses of students showed that ETI 1 and ETI 2 are positive responses with mean (3.28) and (3.01) respectively. Finally, in regards to collaboration and social influence items, the responses of students' revealed that CSI 1, CSI 2, CSI 3 and CSI 4 are positive responses with mean (3.05), (3.67), (3.79) and (3.68) respectively.

In general the result shows that students' attitudes towards during the Coronavirus pandemic is medium and positive for all variables (Educational Process Items, Evaluation and Test Items, Collaboration and Social Influence Items). These findings approved the results of a study that conducted by The Strategic Studies Centre in the University of Jordan study (2020) about Coronavirus and distance education.

Results of Q.3.Is there any statistically significant difference -at the statistical significance level of $(a><0.05)$ - between the students' attitudes towards distance education during the Coronavirus pandemic which can be attributed to (Gender, Living Place, Education)?

To answer this question, means and standard deviations are calculated as shown in table (4).

Table (3): The students' attitudes towards distance education during the Coronavirus pandemic according (Gender, Living Place, Education)

\begin{tabular}{|c|l|c|c|c|}
\hline \multirow{2}{*}{ Variables } & \multicolumn{1}{|c|}{ Category } & No & S.D & M \\
\hline \multirow{2}{*}{ Gender } & Male & 58 & 0.615 & 3.20 \\
\cline { 2 - 5 } & Female & 92 & 0.554 & 3.18 \\
\hline \multirow{3}{*}{ Living Place } & City & 136 & 0.784 & 3.15 \\
\cline { 2 - 5 } & Village & 7.3 & 0.980 & 2.99 \\
\cline { 2 - 5 } & Camp & 116 & 0.321 & 3.11 \\
\hline \multirow{3}{*}{ Educational } & Bachelor & 22 & 0.900 & 3.05 \\
\cline { 2 - 5 } & Master or PhD & 12 & 0.516 & 3.09 \\
\cline { 2 - 5 } & Diploma & 3.15 \\
\hline
\end{tabular}

Based on table (4), it appears that there are difference between the students' attitudes towards distance education during the Coronavirus pandemic which can be attributed to (Gender, Living Place, Education). To identify whether these values are statistically significant or nor -at the statistical significance level of $(a=0.05), A N O V A$ test was conducted to measure if there are any significant differences between the students' attitudes towards distance education during the Coronavirus pandemic which can be attributed to (Gender, Living Place, Education).

Table 5: ANOVA test due to Gender

\begin{tabular}{|l|c|c|c|c|c|}
\hline Category & Sum of Squares & DF & Mean Square & F & Sig. \\
\hline Between Groups & 2.277 & 1 & 2.277 & 2.583 & 0.110 \\
\hline Within Groups & 130.501 & 148 & 0.889 & & \\
\hline Total & 132.779 & 149 & & & \\
\hline
\end{tabular}


Table 6: ANOVA test due to Living Place

\begin{tabular}{|l|c|c|c|c|c|}
\hline Category & Sum of Squares & DF & Mean Square & F & Sig. \\
\hline Between Groups & 4.153 & 1 & 4.153 & 4.779 & 0.33 \\
\hline Within Groups & 128.625 & 148 & 0.869 & & \\
\hline Total & 132.779 & 149 & & & \\
\hline
\end{tabular}

Table7: ANOVA test due to Education

\begin{tabular}{|l|c|c|c|c|c|}
\hline Category & Sum of Squares & DF & Mean Square & F & Sig. \\
\hline Between Groups & 2.650 & 1 & 4.650 & 3.014 & 0.85 \\
\hline Within Groups & 130.129 & 148 & 0.879 & & \\
\hline Total & 132.779 & 149 & & & \\
\hline
\end{tabular}

Based on the results of ANOVA test on distance education during the Coronavirus pandemic (depicted in Table 5, Table 6 and Table 7), the results of such test indicate that there are no significant differences in distance education during the Coronavirus pandemic related to (Gender, Living Place, Education) .

This result may be attributed to the fact that the Corona virus crisis affects all members of society and students and does not exclude anyone, and that distance education is required of all students, so it is expected that the obstacles and trends towards it will be similar.

These results are consistent with the results ofKandilingec (2015) study that have shown there isn't any statistically significant difference between the respondents' attitudes towards e-learning which can be attributed to gender.Awad and Hals (2015) and Al-Zahrani (2020) found that there isn't any statistically significant difference between the respondents' attitudes towards online education .

\section{Conclusion}

The study explore the students' attitudes towards distance education during the Coronavirus pandemic. It was found that the students' attitudes towardsdistance education during the Coronavirus pandemic is medium and positive includes (Educational Process Items, Evaluation and Test Items, Collaboration and Social Influence Items). The students are not compatible with distance education to a large extent. Therefore; universities try to provide all requirements related to distance education.

Its noted that that perhaps during the coming periods, the acceptance of students and society in distance education will increase, as an alternative solution that provides education in case of crises such as the Corona virus crisis.

The study recommends the necessity to provide all the technical and technical requirements for the distance learning process, and to help students acquire appropriate means for distance learning, especially since some of these technologies are expensive.

\section{References:}

First: References in Arabic language:

- Haji, Ahmad Isma'il (2003). Open distance education in universities. Cairo: Egypt, Alam Al-Kotob

- Al-Harbash, Jaser (2003). E-learning experience in the technical faculty in Buraydah. The The First International Symposium on E-Learning. King Faisal Schools. Riyad. 21-23/4/2003. Retrieved from:http://www.kfs.sch.sa/ar/sim.htm

- Al-Harbi, Mesh'alHasan Hameed (2016). The obstacles associated with distance education from the perspective of the students enrolled at King Abed Al-Aziz University. Ain Shams University- Faculty of Education. The Egyptian Association for Reading and Knowledge: Kingdom of SaudiArabia.

- The Strategic Studies Centre in the University of Jordan (2020). Coronavirus and distance education: The Ministry of Education in Jordan.A set of surveys titled (The Jordanian indicator- The public opinion of Jordanian on the street). 17. www.jcss.org

- Al-Zahrani, SawasnDayf Allah Yahya (2020). The attitudes of the faculty members in Um Al-Qurra University towards employing e-learning features: The use of Blackboard Platform in the educational process to address the implications caused by curfew due to the Coronavirus. Arab Journal of Specific EducationThe Arab Journal for Education, Science and Art. 4(13).

- Sana', Saleh Askool (2005). The role of information technologies in improving education at public and private higher education institutions. Unpublished MA thesis. King Abed Al-Aziz University. Jadah.

- Al-Shunak, Qaseem; Abu Hola, Mufdi; Al-Bawab, Abeer and Al-Horani, Mohammad (2003). The impact of using computer and free experiences on the learning of the students majoring in science at the University of Jordan.The Supreme Council for Science and Technology. Amman. Jordan.

- Al-Saleh, Bader bin Abdullah (2006). Distance education: The problematic issues associated with the model: A worksheet presented at the International Conference of Distance Education. Masqat. 
- Amasheh, Mohammad Abduh (2014). Designing a training program that is based on the use of technologies, broadcasting, and social media and its effectiveness in developing some skills in using applications among the teachers of the general educational classrooms and their attitudes towards it. The Arab Association for Instructional Technology. Studies and Research.

- $\quad$ Awad, Muneer; Saeed, Halas; and Mousa, Saqer (2015). Attitudes towards distance education technologies and its relationship with some variables among graduate students in Palestinian universities. The Journal of Al-Aqsa University. 19(1). pp. 219-256.

- The World Health Organization. Retrieved form: https://www.who.int/ar/emergencies/diseases/novelcoronavirus-2019/advice-for-public/q-a-coronaviruses

- The Arab Global Institution, part 27. A'mal for Publication and Distribution. 1996. p. 46.

- Second: References Conducted in English language:

- . Anderson, A. (2008). seven major Challenges for e- learning in developing countries: Case study EBIT, Sir lanka. International journal of education and Development using ICT, 4) 3). Retrieved From: http://www.ijedict.dec.uwi.edu//viewarticle.php?id=472\&layou $\mathrm{t}=\mathrm{html}$

- Conna, B. (2007). An Investigation of incorporating online course in public high school curricula. Retrieved from http://www.proquset.umi.com

- Kandillngeç, Sebnem (2015) Investigation of Students' Attitudes Towards E-Learning in Terms of Different Variables--A Case Study in a Technical and Vocational High School for Girls Educational Research and Reviews, v10 n1 p81-91 